\title{
Needs Assessment of Guidance Counseling in Inclusion School
}

\author{
Asep Sunandar ${ }^{1 *}$, Henny Indreswari ${ }^{1}$, Mohd Hanafi bin Mohd Yasin ${ }^{2}$, Mohd. Mokhtar \\ Bin Tahar ${ }^{2}$, Ahsan Romdhon Junaedi ${ }^{1}$, Diniy Hidayatul Rahman ${ }^{1}$, Wahyudi Siswanto ${ }^{1}$ \\ ${ }^{1}$ Education Faculty, Universitas Negeri Malang, Indonesia \\ ${ }^{2}$ Fakulti Pendidikan Universiti Kebangsaan Malaysia \\ *Corresponding author. Email: asep.sunandar.fip@um.ac.id
}

\begin{abstract}
Inclusive schools are regular schools designated by the Indonesian government to accept ABK as students, Children with special needs (ABK) have a variety of learning and social problems. Obstacles in learning very much depend on the type of disability they carry. The research aims to design a counseling guidance program for $\mathrm{ABK}$ that is tailored to the tasks of child development based on the problems experienced by children through assessment activities. The research process combines theoretical and empirical studies. The study population was all junior high schools that provided inclusion services in Malang City. The results of the study show that BK services are oriented to the conditions and needs of $\mathrm{ABK}$ based on the conditions and types of obstacles children have. So that BK services are more incidental or responsive. BK services are oriented to understanding all the strengths and weaknesses of $\mathrm{ABK}$ with respect to talents, interests, attitudes, feelings and abilities. BK services to understand the educational environment in schools, the environment, family, and the social environment of the community, including tutoring, personal, social guidance and career guidance.
\end{abstract}

Keywords: Counseling guidance, children with disabilities, inclusion school

\section{INTRODUCTION}

Children with disabilities have equal rights, as well as children in general, to get quality education services. Referring to the UU RI No. 8 tahun 2016 tentang Penyandang Disabilitas bahwa mereka memiliki kesamaan kesempatan untuk memperoleh pendidikan yang bermutu di semua jenis, jalur dan jenjang pendidikan secara inklusif atau khusus. Quality education for the disabled is when they can be self-reliant in accordance with their talents, interests and disability conditions. Education services are responsible for facilitating the development of students in all their dimensions so that they can be in the community.

Guidance and counseling services for the disabled, become an integral part of the education service. According to Sunardi (2005) guidance and counseling for the disabled in addition to the purpose of supporting the achievement of educational objectives, more specifically intended to help overcome the learning barriers and developments that have disabilities. In addition, the guidance and counseling program for disability farmers is expected to help develop the totality of the personality of children with disabilities throughout the his humanitarian dimension to the happiness of living in accordance with the values he has adopted.

In the field there are still differences of view on guidance and counseling services between teacher guidance and counseling and special education teachers. The question is whether guidance and counseling services for the disabled are the professional realm of special education teachers or the realm of counseling teachers. In the year 1999, as the number of children with disabilities were disabled in regular American School Counseling Association (ASCA) make a statement that counselors in regular schools are professionally responsible for facilitating and supporting the academic, social-emotional and career development of all learners, including children with cognitive, emotional, medical, behavioral, physical and social obstacles (Nichter dan Edmonson, 2018). In the implementation of guidance and counseling services, according to Terver-Behring and Spagna (2004), some school counselors feel unconfident in serving children 
with special needs, they feel they do not have a provision to serve children with disabilities.

The existence of guidance and counseling services for students with disabilities is needed, but in the implementation is still far from expectation. According to Sunardi (2005) Implementation of guidance and counseling in Sekolah Luar Biasa (SLB) not optimally. Furthermore, according to Sunardi (2005) The implementation of guidance and counseling in SLB tends to be cursory, incidental, or temporal, more responsive, less representative, less varied and sustainable, less grounded in theories, but more based on belief, experience, opinion, about or trial, and not properly administered. This problem arises mainly related to the lack of understanding of teachers to the function of guidance, professionalism (no BK teachers), availability of facilities and infrastructure, and institutional leadership policy issues related to the formulation and implementation of guidance programs.

Current developments, there are policies for guidance and counseling services in SMPLB and SMALB conducted by professional teachers in the field of guidance and counseling. It is made clear through circular letters Direktur Pembinaan Guru Pendidikan Dasar nomor: 7713/B3.3/GT/2019, tanggal 20 September 2019 tentang Persetujuan Linieritas Kualifikasi S-1/D-IV dengan Program Studi PPG Dalam Jabatan. This means that as long as this guidance and counseling service is carried out by the teacher as an additional task, then in the future, the guidance and counseling services in the extraordinary school can be run more professionally, by scholars in the field of guidance and counseling.

Taking into account the implementation of guidance and counseling in SLB, it becomes increasingly concern when students with disabilities in SLB are those who have severe disabilities. Siiring to grow inclusive education, naturally learners with a mild and moderate disability condition will be in a regular school. Meanwhile, in SLB the participants of the students were heavy and double disability or compound. This is in line with the implementation policy of Kurikulum 2013 Pendidikan Khusus, where the curriculum structure and curriculum contents are prepared for the blind, the deaf, the Tunadaksa, the Tunagrahita and the Autis, who have additional barriers/accompanying in intellectual, communication and social interactions. This means that the needs of guidance and counseling services in SLB are increasingly urged to develop the condition of students with severe or even compound disabilities.

Judging by the solution of guidance and counseling services for students with disabilities, there are many problems that have not gained clarity. Among them are:
(1) A model of what guidance and counseling services are suitable for students with disabilities in SLB; (2) What are the material counselling services required by learners in SLB; (3) The implementation strategy and management of counseling services such as what is required by students of disabilities in SLB; (4) Any theoretical frameworks that schedule the basis of how the guidance and counseling services work in the diversity of disability conditions.

\section{METHOD}

This research is conducted by survey, where researchers collect information from respondents by providing a list of written questions or questionnaires. The survey technique was chosen because in the study reached as many SLB teachers as possible research samples. The large amount of Samapel gives an edge from a statistical standpoint.

Data collection In this research is done online through the facilities of Google form. This is done because it is easy and cheap to reach the teachers spread throughout the region of East Java province. Instrument charging time is open for 10 days. Data analysis is conducted through a descriptive quantitative technique, by calculating the frequency, average, standard deviation and percentage for each section.

\section{RESULTS}

Data Exposure

The overall data generated in this study was seen in table 1 . The need for guidance and counseling services for ABK was obtained on average of 100.37 with a standard deviation of 14.14. The BK service Model adapted to the ABK condition was acquired on average of 15.39 with a standard deviation of 2.32 . The BK service to understand all the advantages and disadvantages of the ABK with respect to the talents, interests, attitudes, feelings and capabilities of the average of 31.11 with the standard deviation of 4.73 . The $\mathrm{BK}$ service to understand the education environment in the school, Environment, family, and social environment of the community was obtained on average of 27.99 with the standard deviation of 4.32. And the BK service to address the problems faced in daily life, both in schools and outside schools, was obtained an average of 25.88 with a standard deviation of 4.07 . 
Table 1. Overview of BK service needs in SLB

\begin{tabular}{|c|c|c|c|c|c|}
\hline & $\begin{array}{l}\text { Ser } \\
\text { vice } \\
\text { Mo } \\
\text { del }\end{array}$ & $\begin{array}{l}\text { Underst } \\
\text { anding } \\
\text { Excess } \\
\& \\
\text { Disadva } \\
\text { ntages }\end{array}$ & $\begin{array}{l}\text { Underst } \\
\text { anding } \\
\text { the } \\
\text { educati } \\
\text { on } \\
\text { environ } \\
\text { ment }\end{array}$ & $\begin{array}{l}\text { Troubles } \\
\text { hooting }\end{array}$ & $\begin{array}{l}\text { Couns } \\
\text { eling } \\
\text { Servic } \\
\text { es for } \\
\text { ABK }\end{array}$ \\
\hline $\begin{array}{cl}\mathrm{N} & \text { Vali } \\
\mathrm{d}\end{array}$ & 175 & 175 & 175 & 175 & 175 \\
\hline $\begin{array}{l}\text { Mis } \\
\text { sing }\end{array}$ & 0 & 0 & 0 & 0 & 0 \\
\hline Mean & $\begin{array}{l}15, \\
39\end{array}$ & 31,11 & 27,99 & 25,88 & $\begin{array}{l}100,3 \\
657\end{array}$ \\
\hline $\begin{array}{l}\text { Std. } \\
\text { Deviati }\end{array}$ & $\begin{array}{l}2,3 \\
16\end{array}$ & 4,730 & 4,315 & 4,073 & $\begin{array}{l}14,13 \\
657\end{array}$ \\
\hline $\begin{array}{l}\text { on } \\
\text { Minimu } \\
\text { m }\end{array}$ & 10 & 16 & 17 & 18 & 64,00 \\
\hline $\begin{array}{l}\text { Maxim } \\
\text { um }\end{array}$ & 18 & 36 & 33 & 30 & $\begin{array}{l}117,0 \\
0\end{array}$ \\
\hline
\end{tabular}

\section{Guidance and Counseling service needs for ABK}

There are 39 items of statement to know the needs of guidance and counseling services for the ABK in SLB. Each statement item has an answer scale of 1-3, so the highest grain score is $39 \times 3=117$, the lowest score is 39 $\mathrm{x} 1=39$. Its class intervals consist of three classifications using formula:

Interval class length $=\frac{\text { Highest value }- \text { Lowest value }}{\text { Many interval classes }}$

$$
\text { Interval class length }=\frac{117-39}{3}=
$$$$
26(26)
$$

Thus the length of the interval class and frequency distribution level needs guidance and counseling services for the $\mathrm{ABK}$, defined as in the following table 2 .

Table 2. Frequency distribution Counseling Services for ABK

\begin{tabular}{|c|c|c|c|}
\hline No. & Category & Interval & Frequency \\
\hline 1 & $\begin{array}{l}\text { Very } \\
\text { needed }\end{array}$ & $91-117$ & 126 \\
\hline 2 & Needed & $65-91$ & 49 \\
\hline 3 & No need & $39-64$ & 0 \\
\hline
\end{tabular}

No. Based on table 1 it obtained an average of 100.37 which is located at intervals $91-117$ in much needed category. It can be concluded that the level of guidance and counseling services for $\mathrm{ABK}$ belongs to the category needed, as can be seen in Figure 1 below.

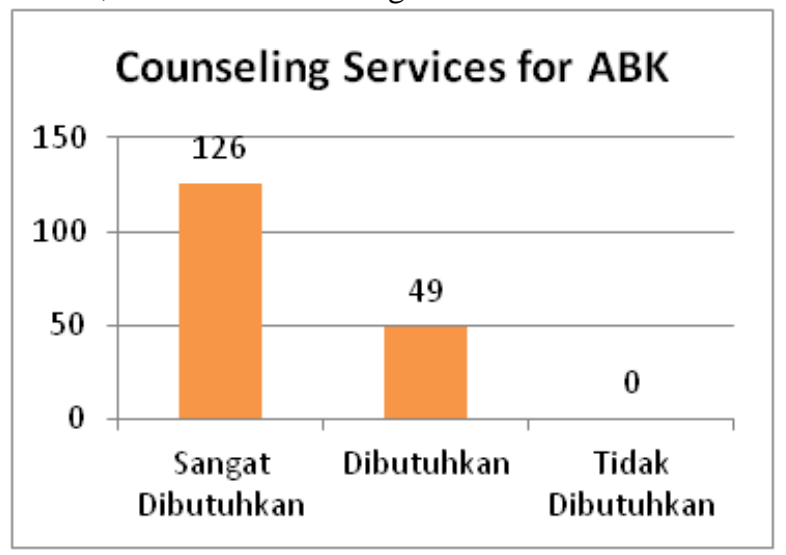

Figure 1. Service level Diagram needs guidance and counseling for ABK

\section{Requirement of service Model BK tailored to ABK condition}

BK service Model adapted to ABK condition, number of instruments as many as 6-item statement with 1-3 answer option, so that the score of the highest grain 6 x $3=18$, lowest score 6 x $1=6$. Its class intervals consist of three classifications using formula:

$$
\begin{aligned}
\text { Interval class length } & =\frac{\text { Highest value }- \text { Lowest value }}{\text { Many interval classes }} \\
& \text { Interval class length }=\frac{18-6}{3}=4
\end{aligned}
$$

Thus the length of the interval class and frequency distribution of the needs of the $\mathrm{BK}$ service model adjusted to the $\mathrm{ABK}$ condition, defined as in table 3.

\begin{tabular}{|c|c|c|c|}
\hline No. & Category & Interval & Frequency \\
\hline 1 & $\begin{array}{l}\text { Very } \\
\text { needed }\end{array}$ & $15-18$ & 113 \\
\hline 2 & Needed & $11-14$ & 61 \\
\hline 3 & No need & $6-10$ & 1 \\
\hline
\end{tabular}

Table 3. Frequency distribution of BK service Model tailored to ABK conditions

According to table 3, it can be explained that the level needs of the BK service model adjusted to the condition of $\mathrm{ABK}$, obtained very needed criteria with a frequency of 113 respondents, required 61 respondents, and not required 1 respondent. Based on table 1, a mean of 15.39 
is located at intervals $15-18$ in a much needed criterion. It can be concluded that the level of needs of the BK service model adjusted to the condition of ABK included in the criteria is needed, as can be seen in Figure 2.

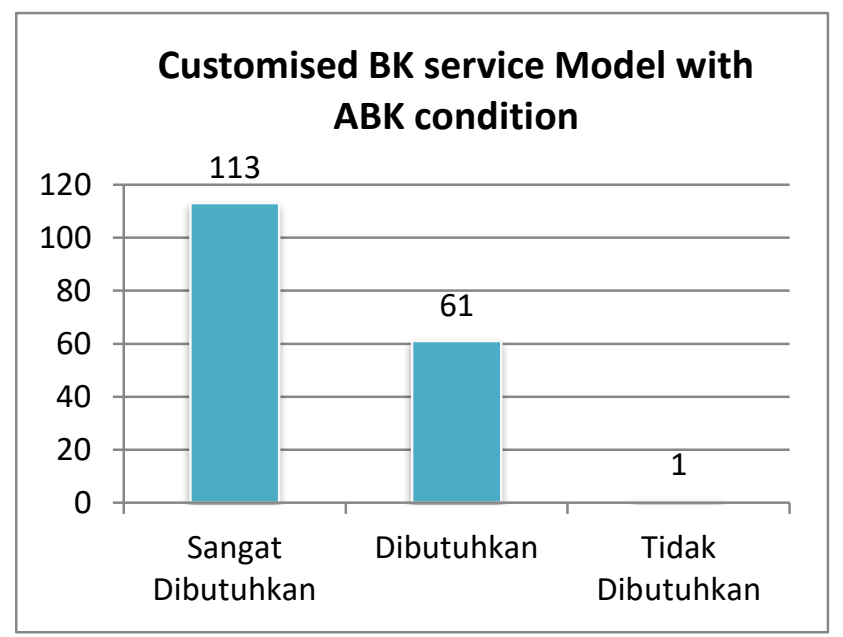

6. BK service needs to understand the advantages and disadvantages of $\mathrm{ABK}$

Guidance and counseling services to understand all the advantages and weaknesses of the ABK with respect to talents, requests, attitudes, feelings and abilities, the number of instruments as many as 12 items with an answer option 1-3, so that the score of the highest item is $12 \times 3=36$, the lowest score is $12 \times 1=12$. Its class intervals consist of three classifications using formula:

$$
\begin{aligned}
\text { Interval class length } & =\frac{\text { Highest value }- \text { Lowest value }}{\text { Many interval classes }} \\
& \text { Interval class length }=\frac{36-12}{3}= \\
& 8(8)
\end{aligned}
$$

Thus the length of the interval class and frequency distribution of the need of $\mathrm{BK}$ to understand all the advantages and weaknesses of the ABK with respect to talents, demands, attitudes, feelings and abilities, is established as in table 4.

\begin{tabular}{|c|c|c|c|}
\hline No. & Category & Interval & Frequency \\
\hline 1 & $\begin{array}{l}\text { Very } \\
\text { needed }\end{array}$ & $29-36$ & 123 \\
\hline 2 & Needed & $21-28$ & 50 \\
\hline 3 & No need & $12-20$ & 2 \\
\hline
\end{tabular}

Table 4. BK frequency distribution to understand all the advantages and disadvantages of ABK

According to table 4 can be explained that the level of need of BK to understand all the advantages and weaknesses owned by the ABK with respect to talents, demands, attitudes, feelings and abilities, gained a much needed criterion with a frequency of 123 respondents, it takes 50 respondents, and no need 2 respondents. Based on table 1 , a mean of 31.11 is located at intervals $29-36$ in a much needed criterion. It can be concluded that the level of need of BK to understand all the advantages and weaknesses owned by the ABK with respect to talents, ask, attitudes, feelings and abilities included in the criteria is much needed, as can be seen in Figure 3.

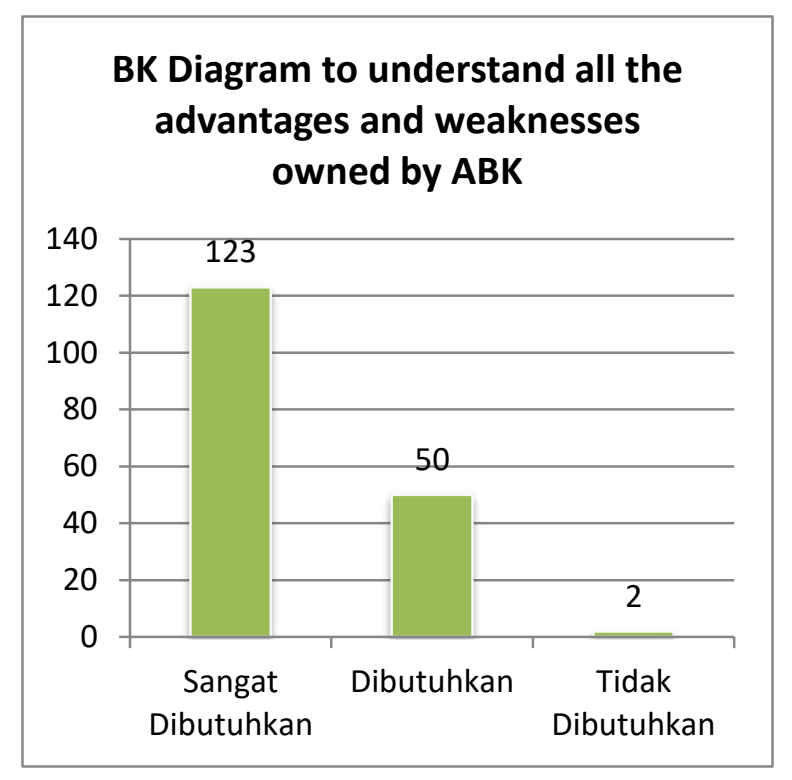

Fig. 3. BK Diagram to understand all the advantages and weaknesses owned by ABK

\section{BK service needs to understand education environment}

BK to understand the educational environment in the school, the environment, the family, and the community social environment, the number of instruments as many as 11 items with the answer option 1-3, so that the score of the highest item $11 \times 3=33$, the lowest score $11 \times 1=11$. Its class intervals consist of three classifications using formula:

$$
\begin{aligned}
\text { Interval class length } & =\frac{\text { Highest value }- \text { Lowest value }}{\text { Many interval classes }} \\
& \text { Interval class length }=\frac{33-11}{3}= \\
& 7,33(8)
\end{aligned}
$$

Thus the length of the interval class and frequency distribution of the need of BK to understand the education environment in the school, Environment, family, and social environment of the community, is set as in table 5 . 
Table 5. BK frequency distribution for understanding the education environment

\begin{tabular}{|c|c|c|c|}
\hline No. & Category & Interval & Frequency \\
\hline 1 & $\begin{array}{l}\text { Very } \\
\text { needed }\end{array}$ & $27-34$ & 112 \\
\hline 2 & Needed & $19-26$ & 62 \\
\hline 3 & No need & $11-18$ & 1 \\
\hline
\end{tabular}

According to table 5 can be exlained that the level of need of BK to understand the education environment in the school, Environment, family, and social environment of the community, obtained the criteria is needed with a frequency of 112 respondents, it takes 62 respondents, and not required 1 respondent. Based on table 1 , a mean of 27.99 is located at intervals $27-34$ in a much needed criterion. Then it can be concluded that the level of need of $\mathrm{BK}$ to understand the education environment in the school, Environment, family, and social environment of the community is included in the criteria is needed, as can be seen in Figure 4.

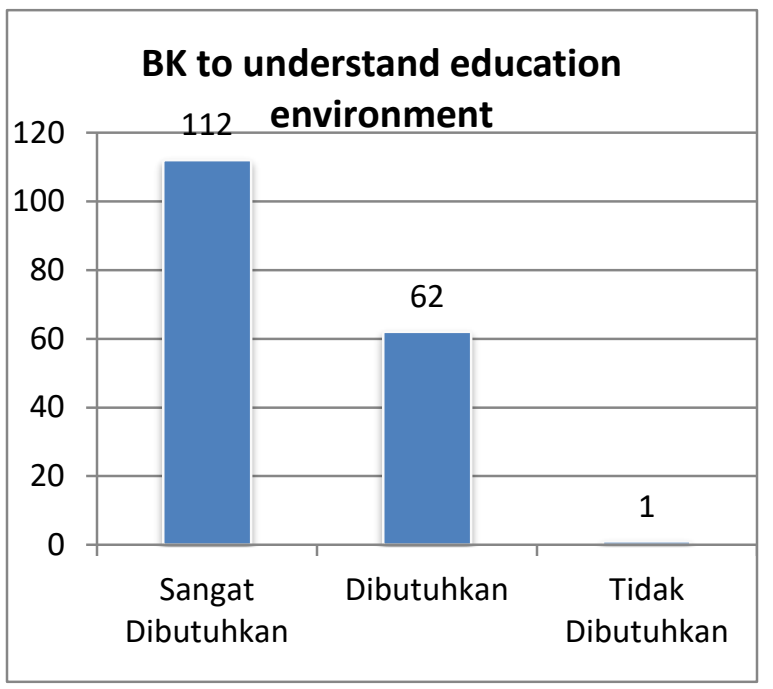

Fig. 4. BK Diagram for understanding the education environment

\section{BK service needs to address problems}

BK to address the problems faced in daily life, both in school and outside the school, the number of instruments as much as 10 items with the answer option $1-3$, so the score of the highest grain $10 \times 3=30$, the lowest score 10 $\mathrm{x} 1=10$. Its class intervals consist of three classifications using formula:

Interval class length $=\frac{\text { Highest value }- \text { Lowest value }}{\text { Many interval classes }}$
Interval class length $=\frac{30-10}{3}=$ $6,67(7)$

Thus the length of the interval class and frequency distribution of the needs of $\mathrm{BK}$ to address the problems faced in daily life, both in school and outside the school, is set as in table 6 .

Table 6. BK frequency distribution for troubleshooting

\begin{tabular}{|c|c|c|c|}
\hline No. & Category & Interval & Frequency \\
\hline 1 & $\begin{array}{l}\text { Very } \\
\text { needed }\end{array}$ & $25-31$ & 111 \\
\hline 2 & Needed & $18-24$ & 64 \\
\hline 3 & No need & $10-17$ & 0 \\
\hline
\end{tabular}

According to table 6 can be explained that the level of need of BK to overcome the problems faced in daily life, both in school and outside school, obtained the criteria is needed with a frequency of 111 respondents, it takes 64 respondents, and no criteria needed no. Based on table 1 , the mean of 25.88 is located at intervals of $25-31$ in much needed criteria. It can be concluded that the level of need for BK to overcome the problems faced in daily life, both at school and outside the school, including in the criteria is needed, as can be seen in Figure 5.

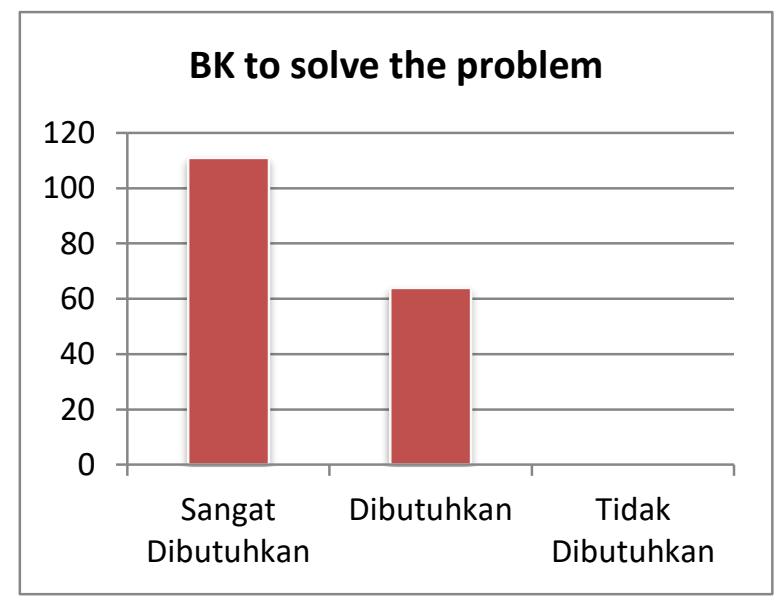

Fig. 5. BK Diagram for troubleshooting

\section{DISCUSSION}

Based on the exposure of data that has been presented in the previous section, it can be concluded that in general the respondent expressed a very need of guidance and counseling services for the ABK. Further (1) BK service 
Model adapted to ABK condition; (2) The services of BK to understand all the advantages and weaknesses of the ABK with respect to talents, interests, attitudes, feelings and abilities; (3) BK services to understand the educational environment in the school, Environment, family, and social environment of the community; (4) The BK service to address the problems faced in daily life, both at school and outside the school, is judged by respondents in a much needed category.

The scope of guidance and counseling services for those with disabilities according to Sunardi (2005) are grouped into basic services and responsive services. Basic services refer to the concept of guidance, which includes information services, placement/distribution, prevention, and maintenance and development, or study guidance activities, education guidance, social guidance, free time charging guidance, personal guidance, or career guidance. Responsive service refers to the concept of counseling, having a special nature, because it is only given to specific students (cases) and is more oriented towards a healing or curative effort.

Findings of this research when categorized into a basic service and responsive service, will be obtained the following conclusions. The BK service understands all the strengths and weaknesses of the ABK with respect to the talents, interests, attitudes, feelings and abilities and services of BK to understand the educational environment of schools, neighborhoods, families, and community social environments, including basic services. While the $\mathrm{BK}$ services are tailored to the conditions of $\mathrm{ABK}$, and the BK service to address the problems faced in everyday life, both at school and outside the school are included in the responsive service. According to Gysber and Henderson the service was responsive to $\mathrm{ABK}$ including services to help address health, social, career and learning developments (Nichter and Edmonson, 2018).

There are several problems that counsellor should consider when providing services for the ABK. These problems are: (1) The influence of disability conditions of physical, social, peikological and cognitive development; (2) Diagnostic problems and ABK placement criteria in education services; (3) Problems How to modify the education intervention to suit the individual needs of the specific ABK (McEachern, 2003). According to Efrod Consulting services to teachers also need to be part of the task or scope of guidance and counseling. Consulting services to teachers include the identification and learning of students with special needs, including consultations in developing interventional strategies and modifying appropriate intervention strategies in the development of individualized Educational Plan (Nichter and Edmonson, 2018).
Guidance and counseling services that are concerned with the condition of disability or a varied special needs of children are needed. According to Terver-Behring and Spagna (2004), counselors should pay attention to the different needs of each disability. For example, children experiencing developmental obstacles (developmental disabilities) counselors are expected to assist parents in developing referral systems for the various services that the child needs. Among them are regular school services, health screening, neurological evaluation, medical and psychiatry assessment, language and speech therapy, physical-motor therapy, and career and vocational guidance.

Burt's research, Scouller and Myrick (1977), recommends that learners experiencing intellectual barriers require guidance and counseling services in relation to problems: (1) personal problems or "selfcentered concern", among them being less confident, less self-control and frequent problems. (2) Guidance and counseling services for children with intelligence barriers relating to financial, employment and future matters. (3) Problems relating to child relationships with other people, such as the ability to make friends and prevent the that hurt others ' feelings.

According to Hall (2015) based on the study conducted recommend five duties of school counselor in serving children with disabilities. (1) Provide individual counselling services. (2) Coordinate with the administrator and supervisor about the needs of education services of children with special needs. (3) Assist or facilitate the techniques of problem solving and conflict resolution for children with disabilities. (4) guiding the scheduling of classes, programs and other related services. (5) Providing career and education guidance services.

\section{CONCLUSION}

The conclusion of this research is that the guidance and counseling services for the ABK in SLB is indispensable. In more detail, the requirements of the $\mathrm{ABK}$ service are required to fulfill the following guiding and counseling characteristics.

1. BK service tailored to the condition of ABK. It means that the BK service is oriented on the condition and needs of ABK based on conditions and types of obstacles owned. So the BK service is more incidental or responsive.

2. The BK service is oriented to understand the advantages and weaknesses of the ABK with respect to talents, interests, attitudes, feelings and abilities.

3. BK services to understand the educational environment in the school, Environment, family, and social 
environment of the community, including the guidance of study, personal and social guidance and career guidance. 4. BK services to address the problems faced in daily life, both at school and outside the school and in the community. It means that the $\mathrm{BK}$ service for $\mathrm{ABK}$ is oriented towards the guidance of resolving problems, adaptation to the learning environment, transition to the community and to the work environment.

\section{REFERENCES}

Burt, M., Scouller, J., dan Myrick, R. (1977). Exceptional Students: Exceptional Needs. Middle School Research Selected Studies, 4:1, 54-60. Online: https://doi.org/10.1080/08851700.1977.11670310

Hall, J. G. (2015). The School Counselor and Special Education: Aligning Training with Practice. The Professional Counselor, Volume 5, Issue 2, Pages 217-224. Online: http://tpcjournal.nbcc.org doi:10.15241/jgh.5.2.217

Hansen, C., E. (1971). The Special Education Counselor: A New Role. The Kisher Body Alphabet: USA.

McEachern, A., G. (2003). School Counselor Preparation to Meet the Guidance Needs of Exceptional Students: A National Study. Counselor Education \& Supervision, June 2003. Volume 42, PP. 314325.

Online: https://onlinelibrary.wiley.com/doi/abs/10.1002/j.1 556-6978.2003.tb01822.x

Nichter, M., dan Edmonson, S., L. (2005). Counseling Services for Special Education Students. Journal of Professional Counseling: Practice, Theory \& Research, 33:2, 50-62. Online: https://doi.org/10.1080/15566382.2005.12033817

Myrick, R., D. (2011). Developmental Guidance and Counseling: A Practical Approach. Educational Media Corporation: Minneapolis USA.

Sunardi, (2005). Pedoman Pelaksanaan Program Layanan Bimbingan dan Konseling di Sekolah Luar Biasa. Jurusan PLB FIP Universitas Pendidikan Indonesia. Bandung. Online: https://docplayer.info/35071064-Pedomanpelaksanaan-program-layanan-bimbingan-dankonseling-di-sekolah-luar-biasa.html

Terver-Behring, S., Spagna, M. E. (2004). Counseling with Exceptional Children. Focus on Exceptional Children. Volume 36 Number 8 April 2004. Online:

https://www.researchgate.net/publication/2347046

90_Counseling_With_Exceptional_Children 